\title{
Highly Connected Two-Dimensional Crystals of DNA Six-Point-Stars
}

Yu He, Ye Tian, Alexander E. Ribbe, and Chengde Mao*

Department of Chemistry, Purdue University, 560 Oval Drive, West Lafayette, Indiana 47907, USA

\section{Supporting Information}

\section{Experimental Methods}

Oligonucleotides. DNA sequences were designed by a computer program "SEQUIN" (N. C. Seeman, J. Biomol. Struct. Dyn. 1990, 8, 573-581.) Oligonucleotides were purchased from Integrated DNA Technologies, Inc., and purified by denaturing polyacrylamide gel electrophoresis (PAGE).

\section{DNA sequences.}

six-point-star motif with blunt-ends

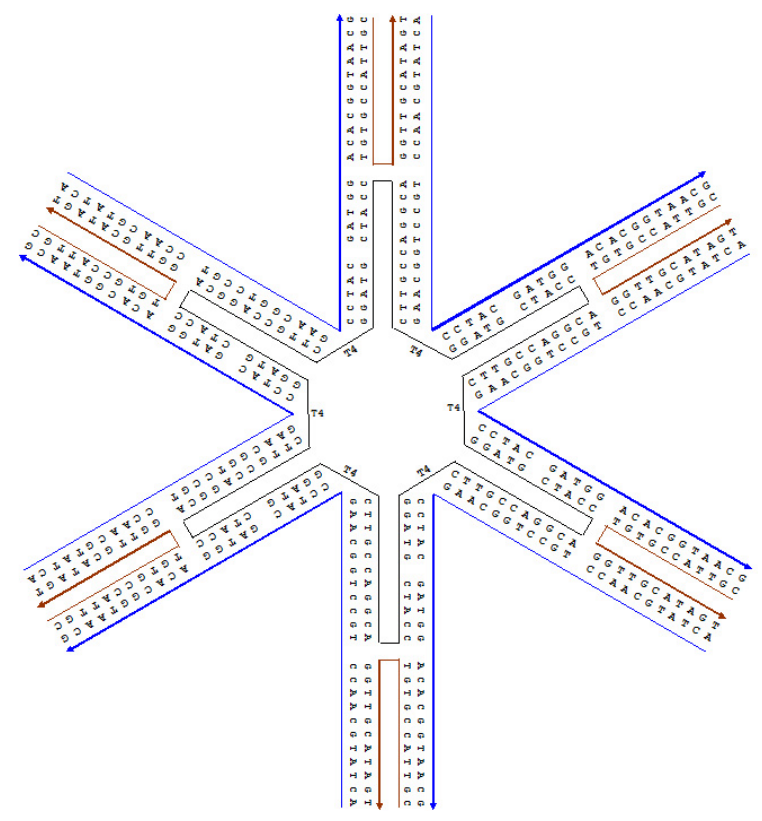

six-point-star motif with sticky-ends

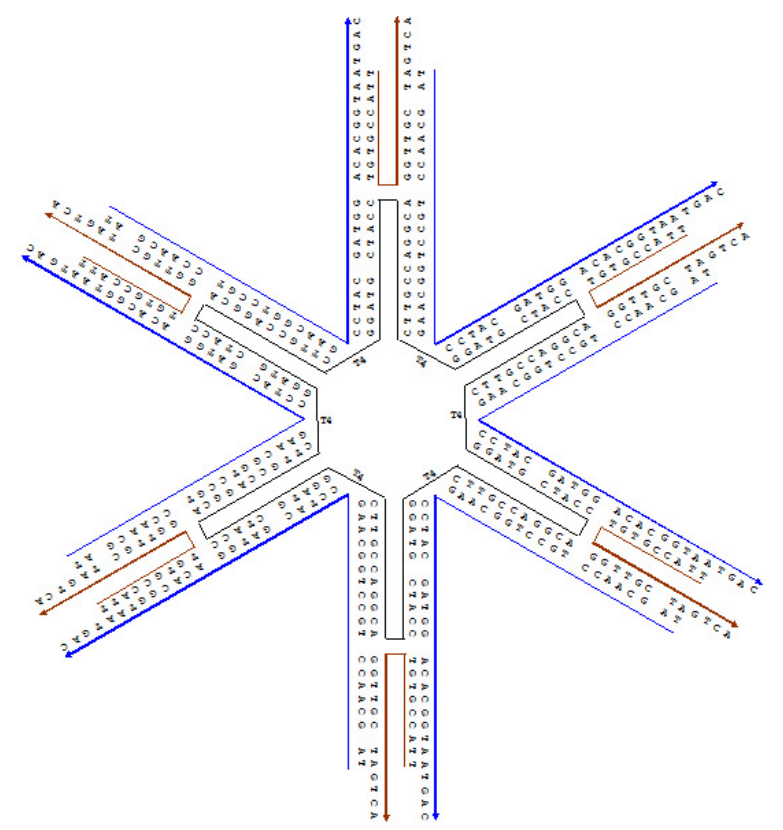

Preparation of the black, central, cirular strand. Strands A (4 nmole) and B (4 nmole) were mixed with 50 units of T4 polynucleotide kinase (New England Biolabs, Inc., NEB) in $400 \mu \mathrm{l}$ kination buffer, which contained $1 \mathrm{mM}$ ATP, $66 \mathrm{mM}$ Tris-HCl, $\mathrm{pH} 7.6,6.6 \mathrm{mM} \mathrm{MgCl} 2$ and 10 $\mathrm{mM}$ dithiothreitol (DTT). The mixture was incubated at $37^{\circ} \mathrm{C}$ for 4 hours and then at $95^{\circ} \mathrm{C}$ for 5 minutes. To the kination mixture, 24 nmole strand $\mathrm{L}$ in $400 \mu$ kination buffer was added. The mixture was annealed from $95^{\circ} \mathrm{C}$ to $22^{\circ} \mathrm{C}$ over $30 \mathrm{~min}$. Upon addition of 600 units $\mathrm{T} 4$ Polynucleotide ligase (NEB), the mixture was incubated at $22^{\circ} \mathrm{C}$ for 16 hours. Finally, the 
circular central DNA strand (150 bases long) was purified by $10 \%$ denaturing PAGE. Strand A: 5'-gCC Agg CAC CAT CgT Agg TTT TCT TgC CAg gCA CCA TCg TAg gTT TTC TTg CCA ggC ACC ATC gTA ggT TTT CTT gCC-3'. Strand B: 5'-Agg CAC CAT CgT Agg TTT TCT TgC CAg gCA CCA TCg TAg gTT TTC TTg CCA ggC ACC ATC gTA ggT TTT CTT-3'. Strand L: 5'-gAT ggT gCC Tgg CAA gAA AAC-3'

Native Polyacrylamide Gel Electrophoresis (PAGE). Gel contained 5\% polyacrylamide (19:1 acrylamide/bisacrylamide) was run on a FB-VE10-1 electrophoresis unit (FisherBiotech) at $4{ }^{\circ} \mathrm{C}$ ( $80 \mathrm{~V}$, constant voltage). After electrophoresis, the gels were stained with Stains-all dye (Sigma) and scanned. The running buffer of the electrophoresis is a Tris/acetate/EDTA/ $\mathrm{Mg}^{2+}\left(\mathrm{TAE} / \mathrm{Mg}^{2+}\right)$ buffer; which consisted of Tris $(40 \mathrm{mM}, \mathrm{pH} 8.0)$, acetic acid $(20 \mathrm{mM})$, EDTA (2 mM), and $\mathrm{Mg}\left(\mathrm{CH}_{3} \mathrm{COO}\right)_{2}(12.5 \mathrm{mM})$.

Formation of DNA complexes and $2 D$ arrays. The black, blue, and red DNA strands were combined in TAE/ $\mathrm{Mg}^{2+}$ buffer. Individual DNA complexes for native PAGE analysis were formed by cooling solutions of the mixtures as follows: $95{ }^{\circ} \mathrm{C} / 2 \mathrm{~min}, 65{ }^{\circ} \mathrm{C} / 10 \mathrm{~min}, 55{ }^{\circ} \mathrm{C} / 10$ $\min , 45{ }^{\circ} \mathrm{C} / 10 \mathrm{~min}, 35{ }^{\circ} \mathrm{C} / 15 \mathrm{~min}, 25{ }^{\circ} \mathrm{C} / 15 \mathrm{~min}, 15{ }^{\circ} \mathrm{C} / 15 \mathrm{~min}$, and $4{ }^{\circ} \mathrm{C} / 30 \mathrm{~min}$. DNA 2D arrays were formed by slowly cooling the DNA solution (The black, blue, and red DNA single strands mixed with molar ratio of $1: 6: 6$ in TAE/ $\mathrm{Mg}^{2+}$ buffer) from $95{ }^{\circ} \mathrm{C}$ to room temperature over 48 hours. The central DNA (black) with concentration ranging from $0.6 \mu \mathrm{M}$ to $4 \mu \mathrm{M}$ was used in the experiments.

AFM imaging. $5 \mu \mathrm{L}$ DNA solution (in TAE/ $\mathrm{Mg}^{2+}$ buffer) was dropped onto freshly cleaved mica (Ted Pella, Inc.) and left to adsorb to the surface for $3 \mathrm{~min}$. Buffer $\left(\mathrm{TAE} / \mathrm{Mg}^{2+}\right.$ ) in volume of around $30 \mu \mathrm{L}$ was then added to the drops on the mica. Imaging was performed in a fluid cell in tapping mode on a Multimode NanoScope IIIa (Digital Instruments) with NP-S tips (Veeco, Inc.). The tip velocity was kept at $10 \mu \mathrm{m} / \mathrm{s}$, otherwise a scan frequency of $1 \mathrm{~Hz}$ or lower was used. The tip-surface interaction was minimized by optimizing the scan set-point.

Fluorescence Microscope Imaging. $3 \mu \mathrm{L}$ of DNA solution (in TAE/ $\mathrm{Mg}^{2+}$ buffer) was spotted onto clean glass slide, and sat there for $15 \mathrm{~min}$ to allow DNA arrays to absorb onto glass surface. Then $1 \mu \mathrm{L}$ of YOYO- 1 solution $\left(1.7 \mu \mathrm{M}\right.$ in TAE/ $\mathrm{Mg}^{2+}$ buffer $)$ was spotted onto the DNA sample. The YOYO-1 stained DNA sample was immediately covered with a coverslip and imaged with a fluorescence microscope. The images were taken with an excitation wavelength of $450 \mathrm{~nm}$ and an emission wavelength of $520 \mathrm{~nm}$. 